\title{
CHANGES IN BLOOD VOLUME IN PATIENTS WITH EDEMA OF RENAL ORIGIN
}

\author{
BY R. L. WATERFIELD \\ (From the Chemical Division of the Medical Clinic, the Johns Hopkins Hospital and \\ University, Baltimore)
}

(Received for publication August 27, 1930)

The purpose of the present study was to apply the carbon monoxide method to the investigation of the circulating blood volume in cases of renal edema, and to follow by this means the changes in the blood volume of patients during the disappearance or reappearance of their edema. The problem appeared to us one of particular interest in view of the fact that the investigations that have been published so far have, with few exceptions, been carried out by means of the dye method; moreover the results that have been obtained by that method have shown remarkable differences in the hands of different observers, two groups of workers getting with it results not only opposed, but diametrically opposed, to one another.

In looking through the literature it appears that three cases reported by Plesch are the only ones in which the blood volume determinations were made by methods other than the dye method. In 1909 (2) with his infusion method he found in a case of renal edema of the most extreme degree a blood volume that was only half the normal. In 1922 (1) with the carbon monoxide method the same author found in two cases of renal edema a small volume which increased as the edema became less.

In 1924 (3) Linder and Lundsgaard found in cases of renal edema normal plasma volume using the dye method.

In 1926 (4) Darrow reported four cases of nephritic edema-three children and one adult in which the blood volume had been determined by the dye method. In all four cases the blood volume was diminished, whether calculated as volumes per unit of actual weight or as volumes per unit of edema-free weight. In two of the cases- 
both children, diagnosed nephrosis with no elevation of nonprotein nitrogen or blood pressure-subsequent determination during the disappearance of the edema showed a great increase in the blood volume which was mainly in the plasma fraction.

In 1927 (5) a number of blood volume determinations by the dye method in acute and subacute glomerular nephritis were reported by Rusznyák who found the blood volume slightly diminished.

In 1925 (6) Brown and Rowntree, using their dye method, had already investigated four cases of nephrosis and four cases of subacute glomuerular nephritis; and in 1928 (7) the same authors published an additional series of nine cases of nephrosis and twelve cases of glomerular nephritis. They concluded that whereas the cases of glomerular nephritis gave in general low or low-normal volumes with normal plasma volumes but decreased cell volumes, the cases of nephrosis gave, when uncomplicated by anemia, normal volumes and, when anemia was present, volumes that were somewhat increased both in respect of the whole blood and of the plasma. They differentiated also between these two groups in regard to the mechanism of diuresis: in glomerular nephritis disappearance of the edema was generally accompanied by a further reduction of the blood volume due mainly to a fall in cell volume in consequence of the progressive anemia; while in nephrosis no constant change was observed during diuresis either in cell or plasma volumes.

The point of greatest interest in the foregoing results is the remarkable divergence among them: on the one hand Brown and Rowntree find in nephrosis normal or increased plasma volumes with little or no change during diuresis; on the other hand Darrow obtains volumes markedly decreased in respect of both whole blood and plasma, with great increase in both during diuresis. The two cases of Plesch give low volumes with increasing volume during diuresis. One cannot be sure from his data whether they were cases of nephrosis or glomerular nephritis, but in either case they behave during diuresis in the opposite way to the cases of Brown and Rowntree. Yet it must be realized that there are two facts which may possibly account for the discrepancies: first, that Darrow worked with children and Brown and Rowntree with adults, and secondly that Brown and Rowntree used the dye method while Pelsch used the carbon monoxide method. 
METHOD

In our own studies on the blood volume in cases of renal edema we have used throughout the modification of Haldane's carbon monoxide method described by Chang and Harrop (8); in fact we have used the actual apparatus which they constructed. We have, however, introduced the precaution of standardizing the posture of the patient (in view of the work of Thompson, Thompson and Daily (9) ), keeping them lying in bed for at least twelve hours prior to each determination.

In all cases the carbon monoxide content of the blood was determined in a sample drawn before rebreathing of the gas was started, and this figure was subtracted from the carbon monoxide content after rebreathing, in order to obtain the percentage of carbon monoxide that was present as a result of the inhalation alone.

TABLE 1

Blood volumes of eight normal adults in the recumbent posture

\begin{tabular}{|c|c|c|c|}
\hline & $\begin{array}{l}\text { Whole blood, } \\
\text { cc. per kgm. } \\
\text { ideal weight }\end{array}$ & $\begin{array}{l}\text { Plasma. } \\
\text { cc. per kgm. } \\
\text { ideal weight }\end{array}$ & $\begin{array}{l}\text { Cells, } \\
\text { cc. per kgm. } \\
\text { ideal weight }\end{array}$ \\
\hline Average.... & 71.4 & 40.5 & 30.9 \\
\hline 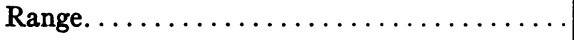 & $61.8-82.3$ & $35.6-47.2$ & $26.3-36.4$ \\
\hline
\end{tabular}

In eight normal adult males the blood in cc. per kgm. ideal weight was found by this method and with the same apparatus and technique to have the average figures and range of variation in the recumbent posture as shown in table 1 .

\section{CASES AND RESULTS}

Five cases were studied. On all but one of them several blood volume determinations were made. In every case the actual blood volume was calculated, and also the blood volume in cubic centimeters per kilogram of ideal weight. The ideal weight was employed because of the large amount of edema present.

Case 1. M. L., number 17,816. Age 42 years, Italian housewife. Diagnosis: anasarca; transient albuminuria; toxemia of pregnancy; nephrosis.

She was admitted April 10, 1928, one month after her seventh normal delivery, with general anasarca which had started to appear during the last few weeks of 
pregnancy. On admission there was considerable edema of the legs with ascites. There was no anemia. The urine showed a trace of albumin, no casts and a very occasional red cell; the specific gravity was 1020 and the reaction acid. The blood pressure was $160 / 100 \mathrm{~mm}$. Hg. The nonprotein nitrogen had the normal figure of $33 \mathrm{mgm}$. per $100 \mathrm{cc}$. As shown in table 2 the cholesterol content of the plasma was raised while the serum protein had a remarkably low value. There was an inverted albumin-globulin ratio of 0.47 to 0.53 .

On a high protein diet the serum protein rose rapidly and at the same time the albumin in the urine, which had previously been only a trace, increased to a large daily output.

Finally the serum protein reached a normal figure of between 6 and 7 grams per $100 \mathrm{cc}$., the albuminuria ceased and the edema disappeared. The blood pressure also fell, and was $118 / 63 \mathrm{~mm}$. $\mathrm{Hg}$ on her discharge six weeks after admission.

TABLE 2

Variations in blood volume with disappearance of edema. Case 1

\begin{tabular}{|c|c|c|c|c|c|c|c|c|c|c|c|}
\hline \multirow{2}{*}{ Date } & \multirow{2}{*}{ Weight } & \multirow{2}{*}{$\begin{array}{l}\text { Hemo- } \\
\text { globin }\end{array}$} & \multirow{2}{*}{$\begin{array}{l}\text { Total } \\
\text { protein }\end{array}$} & \multirow{2}{*}{$\begin{array}{l}\text { Choles- } \\
\text { terol }\end{array}$} & \multirow{2}{*}{\begin{tabular}{|c} 
Hema- \\
tocrit
\end{tabular}} & \multicolumn{3}{|c|}{ Volume } & \multicolumn{3}{|c|}{$\begin{array}{l}\text { Volume per kgm. } \\
\text { ideal weight }\end{array}$} \\
\hline & & & & & & $\begin{array}{l}\text { Whole } \\
\text { blood }\end{array}$ & Plasma & Cells & $\begin{array}{l}\text { Whole } \\
\text { blood }\end{array}$ & Plasma & Cells \\
\hline 1928 & $\mathrm{kgm}$. & per cent & $\begin{array}{c}\text { grams } \\
\text { per } \\
100 \mathrm{cc} .\end{array}$ & $\begin{array}{c}\mathrm{mgm.} \\
\text { per } \\
100 \mathrm{cc.}\end{array}$ & \begin{tabular}{|} 
percent- \\
age of \\
cell \\
volume
\end{tabular} & liters & liters & liters & $c c$ & $c c$. & $c c$. \\
\hline April 1 & 74 & 99 & 2.6 & 167 & 51.5 & 3.21 & 1.60 & 1.65 & 54.9 & 27.4 & 28.2 \\
\hline May 2 & 50 & 96 & 6.1 & 329 & 44.5 & 3.69 & 2.05 & 1.64 & 63.1 & 35.1 & 28.1 \\
\hline May 11 & 50 & 96 & 6.5 & 256 & 42.5 & 3.93 & 2.26 & 1.67 & 67.2 & 38.7 & 28.6 \\
\hline
\end{tabular}

In this case there was no anemia. The blood volume was low, entirely in respect of plasma, the cell volume being normal. With the subsidence of the edema the plasma volume rose to within normal limits and the cell volume underwent no change.

Case 2. L. E., number 16,501. Autopsy number 11030. Age 24 years. White male, previously an attendent in a gasoline filling station. Diagnosis: chronic nephritis.

Patient was admitted January 27,1928 , for massive edema involving most of the body, ascites and bilateral hydrothorax. In the three preceding years he had had three sudden attacks of swelling commencing in his legs and spreading up to his abdominal wall; the first two attacks lasted several months and had subsided suddenly and spontaneously; the third had persisted over a year up to the time of admission. There was no history of infection. 
On admission, the red blood count was 3.7 million and the white count 13,000 . The blood pressure was $176 / 110 \mathrm{~mm}$. Hg. There were no retinal changes. The urine showed a massive albuminuria, a few granular and hyaline casts, and numerous doubly refractile crystals; there were no red cells and the specific gravity was 1030. The blood examination gave a nonprotein nitrogen of $31 \mathrm{mgm}$. per $100 \mathrm{cc}$; serum protein of 4.2 grams per $100 \mathrm{cc}$. with inverted albumin-globulin ratio of 9.43 to 0.57 ; and a high cholesterol of $410 \mathrm{mgm}$. per $100 \mathrm{cc}$.

His weight on admission was $120 \mathrm{kgm}$. and on discharge 4 months later it had fallen to $78 \mathrm{kgm}$.

Four months later he was readmitted for a few days to repeat the blood volume and other determinations. Except for the loss of an additional $4 \mathrm{kgm}$. of weight and a progression in his anemia he was much the same as he had been 4 months previously. His red cell count had fallen to 2.5 million, his nonprotein nitrogen

TABLE 3

Variations in blood volume with disappearance of edema. Case 2

\begin{tabular}{|c|c|c|c|c|c|c|c|c|c|c|c|}
\hline \multirow{2}{*}{ Date } & \multirow{2}{*}{ Weight } & \multirow{2}{*}{$\begin{array}{l}\text { Hemo- } \\
\text { globin }\end{array}$} & \multirow{2}{*}{$\begin{array}{l}\text { Total } \\
\text { protein }\end{array}$} & \multirow{2}{*}{$\begin{array}{c}\text { Choles- } \\
\text { terol }\end{array}$} & \multirow{2}{*}{$\underset{\text { tocrit }}{\text { Hema- }}$} & \multicolumn{3}{|c|}{ Volume } & \multicolumn{3}{|c|}{$\begin{array}{l}\text { Volume per kgm. } \\
\text { ideal weight }\end{array}$} \\
\hline & & & & & & $\begin{array}{l}\text { Whole } \\
\text { blood }\end{array}$ & Plasma & Cells & $\begin{array}{l}\text { Whole } \\
\text { blood }\end{array}$ & Plasma & Cells \\
\hline 1928 & kgm. & per cent & $\begin{array}{c}\text { grams } \\
\text { per } \\
100 \text { cc. }\end{array}$ & $\begin{array}{c}\text { mgm. } \\
\text { per } \\
100 \mathrm{cc} .\end{array}$ & $\begin{array}{l}\text { percent- } \\
\text { age of } \\
\text { cell } \\
\text { volume }\end{array}$ & liters & liters & liters & $c c$. & $c c$. & cc. \\
\hline January 31 & 116 & 62 & 4.2 & 410 & 34 & 3.99 & 2.63 & 1.35 & 55.5 & 36.4 & 18.9 \\
\hline $\operatorname{March} 2$ & 109 & 63 & 3.5 & 306 & 31 & 5.16 & 3.56 & 1.60 & 71.7 & 49.5 & 22.2 \\
\hline April 13 & 88 & 62 & 3.8 & & 29 & 5.14 & 3.45 & 1.69 & 71.5 & 48.0 & 23.5 \\
\hline May 21 & 80 & 60 & & & 31 & 4.89 & 3.37 & 1.52 & 67.9 & 46.9 & 21.1 \\
\hline October 20 & 74 & 45 & 4.6 & 313 & 25 & 5.28 & 3.96 & 1.32 & 73.4 & 55.0 & 18.4 \\
\hline
\end{tabular}

was $45 \mathrm{mgm}$. per $100 \mathrm{cc}$. and his blood pressure $185 / 110 \mathrm{~mm}$. Hg. There was still massive albuminuria, but in addition numerous casts and very occasional red cells were now present.

Eight months later he was readmitted in uremia and died.

In this case as shown in table 3 the blood volume was low, the plasma volume was on the lower limit of normal and the cell volume below the normal figure. There was a considerable anemia. After diuresis had set in the blood volume rose to the normal figure mainly as the result of a great increase in plasma volume which rose above the normal value. The cell volume also increased at first, but finally fell again with the progress of the anemia. In the last determination the total blood volume was still within normal limits despite the very 
low cell volume, because the plasma volume had risen well above the normal level.

Case 3. C. C. number 19,889. Age 27 years. White male, stationary engineer. Diagnosis: chronic nephritis with chronic sinusitis. Admitted August 5, 1928 for general anasarca.

Eight months earlier the swelling had started in the legs and had become generalized four weeks before admission.

On admission there was found to be generalized edema and a bilateral hydrothorax. The blood pressure was $122 / 72 \mathrm{~mm}$. Hg. The red blood count was 4.7 million, and the white count 17,000 . The urine contained great quantities of albumin, numerous casts, but no red cells. The nonprotein nitrogen was 70 mgm., cholesterol $500 \mathrm{mgm}$., total protein 3.3 , grams per $100 \mathrm{cc}$., and there was an inverted albumin-globulin ratio of 0.30 to 0.70 .

TABLE 4

Variations in blood volume as edema increased and diminished. Case 3

\begin{tabular}{|c|c|c|c|c|c|c|c|c|c|c|c|}
\hline \multirow{2}{*}{ Date } & \multirow{2}{*}{ Weight } & \multirow{2}{*}{$\begin{array}{l}\text { Hemo- } \\
\text { globin }\end{array}$} & \multirow{2}{*}{\begin{tabular}{|c|} 
Total \\
protein
\end{tabular}} & \multirow{2}{*}{$\begin{array}{c}\text { Choles- } \\
\text { terol }\end{array}$} & \multirow{2}{*}{$\underset{\text { tocrit }}{\text { Hema- }}$} & \multicolumn{3}{|c|}{ Volume } & \multicolumn{3}{|c|}{$\begin{array}{l}\text { Volume per kgm. } \\
\text { ideal weight }\end{array}$} \\
\hline & & & & & & $\begin{array}{l}\text { Whole } \\
\text { blood }\end{array}$ & Plasma & Cells & $\begin{array}{l}\text { Whole } \\
\text { blood }\end{array}$ & Plasma & Cells \\
\hline 1928 & kgm. & percent & $\begin{array}{c}\text { grams } \\
\text { per } \\
100 \text { cc. }\end{array}$ & $\begin{array}{c}\text { mgm. } \\
\text { per } \\
100 \text { cc. }\end{array}$ & $\begin{array}{c}\text { percent- } \\
\text { age of } \\
\text { cell } \\
\text { volume }\end{array}$ & liters & liters & liters & $c c$. & $c c$. & $c c$. \\
\hline September 1 & 73 & 92 & 3.3 & & 36.5 & 4.10 & 2.60 & 1.50 & 63.5 & 40.3 & 23.3 \\
\hline November 3 & 77 & 69 & 4.5 & 820 & 36.0 & 3.23 & 2.07 & 1.16 & 50.1 & 32.1 & 18.0 \\
\hline December 17 & 54 & 50 & 4.0 & 396 & 27.0 & 3.97 & 2.90 & 1.07 & 61.5 & 45.0 & 11.6 \\
\hline
\end{tabular}

The patient's weight gradually increased during the first three months from 68 to $79 \mathrm{kgm}$. Acupuncture was then performed and repeated with a resulting reduction of weight to $52 \mathrm{kgm}$. in one month. He went home at Christmas for six weeks and then returned to the hospital for another three months study, during which time his weight varied between 66 and $58 \mathrm{mgm}$.

During the period in which he was under observation the blood pressure tended to rise and the anemia to increase, but the nonprotein nitrogen fell slightly. The urine underwent little change. At the time of his final discharge the blood pressure was $140 / 100 \mathrm{~mm}$. $\mathrm{Hg}$, and the red blood count was 3.0 million.

In this case (see table 4) on admission the whole blood and cell volume was low or near the lower limits of normal. The plasma volume was normal. With increasing edema the plasma volume fell markedly and the cell volume also fell with the progress of the anemia. 
Later as the edema disappeared the blood volume approached again the lower limits of normal despite the still further diminishing cell volume, owing to the fact that the plasma volume had risen above the normal.

Case 4. N. M., number 16,638. Autopsy, number 10661. Age 47 years. German housewife. Diagnosis: chronic nephritis, arteriorsclerosis, hypertension, myocardial insufficiency. Admitted February 3, 1928, for general anasarca.

The swelling of the legs had started two months before admission. More recently the abdomen had begun to swell, there had been puffiness of the face, misty vision, dyspnea on exertion and weakness.

There was found on examination generalized edema, ascites añd a bilateral hydrothorax. The heart was large and there was marked albuminuric retinitis. The blood pressure varied between $200 / 120$ and $220 / 160 \mathrm{~mm}$. $\mathrm{Hg}$. The urine

TABLE 5

Variations in blood volume with variations in amount of edema. Case 4

\begin{tabular}{|c|c|c|c|c|c|c|c|c|c|c|c|}
\hline \multirow{2}{*}{ Date } & \multirow{2}{*}{ Weight } & \multirow{2}{*}{$\begin{array}{l}\text { Hemo- } \\
\text { globin }\end{array}$} & \multirow{2}{*}{$\begin{array}{c}\text { Total } \\
\text { protein }\end{array}$} & \multirow{2}{*}{$\begin{array}{c}\text { Choles- } \\
\text { terol }\end{array}$} & \multirow{2}{*}{$\underset{\text { tocrit }}{\text { Hema- }}$} & \multicolumn{3}{|c|}{ Volume } & \multicolumn{3}{|c|}{$\begin{array}{l}\text { Volume per kgm. } \\
\text { ideal weight }\end{array}$} \\
\hline & & & & & & $\begin{array}{l}\text { Whole } \\
\text { blood }\end{array}$ & Plasma & Cells & $\begin{array}{c}\text { Whole } \\
\text { blood }\end{array}$ & Plasma & Cells \\
\hline 1928 & $\mathrm{kgm}$. & per cent & $\begin{array}{c}\text { grams } \\
\text { per } \\
100 \text { cc. }\end{array}$ & $\begin{array}{c}\text { mgm. } \\
\text { per } \\
100 \mathrm{cc} .\end{array}$ & $\begin{array}{l}\text { percent- } \\
\text { age of } \\
\text { cell } \\
\text { volume }\end{array}$ & liters & liters & liters & $c c$. & $c c$. & $c c$. \\
\hline February 17 & 68 & 85 & 4.1 & 248 & 40 & 3.70 & 2.22 & 1.48 & 59.2 & 38.5 & 23.7 \\
\hline March 3 & 60 & 75 & 5.0 & & 32 & 4.63 & 3.15 & 1.48 & 74.1 & 50.4 & 23.7 \\
\hline May 17 & 69 & 80 & 4.2 & 186 & 32 & 4.12 & 2.80 & 1.32 & 65.9 & 44.8 & 21.1 \\
\hline
\end{tabular}

contained large quantities of albumin, casts, and red cells. The red cell count was 4.1 million, the nonprotein nitrogen $42 \mathrm{mgm}$., total protein 4.7 grams per $100 \mathrm{cc}$. with inverted albumin-globulin ratio of 0.30 to 0.70 . The cholesterol was $360 \mathrm{mgm}$. per $100 \mathrm{cc}$.

She was readmitted on a number of occasions owing to the return of the anasarca; and, although she improved temporarily each time, her progress was steadily down-hill. At the final admission, ten months after she was first seen, her nonprotein nitrogen had risen to over $100 \mathrm{mgm}$. per $100 \mathrm{cc}$. and she died in uremia.

On the first determination, when there was considerable edema, the blood volume was below normal. With the disappearance of the edema the plasma volume rose markedly to a value above normal, the cell volume remaining unchanged. On returning to the hospital the 
second time with more edema the plasma volume had fallen again, the cell volume being only slightly less than what it was previously. (See table 5.)

Case 5. A. S., number 26,662. Age 49 years, White male, "steamfitter." Diagnosis: chronic diffuse nephritis. Admitted September 3, 1929 for general anasarca.

The swelling had started gradually one year before admission. This patient was very uncomfortable and it was impossible to subject him to a blood volume determination except on one occasion. He reacted scarcely at all to the various forms of treatment instituted. There was considerable anemia present, the red cell count being around 3 million. The nonprotein nitrogen was $50 \mathrm{mgm}$., the cholesterol ranged between 165 and $250 \mathrm{mgm}$., the total protein was 3.8 grams

TABLE 6

Blood volumes in five cases of nephritis at time of maximum edema

\begin{tabular}{|c|c|c|c|c|c|c|c|c|c|c|c|}
\hline \multirow{2}{*}{ Case } & \multirow{2}{*}{ Age } & \multirow{2}{*}{$\begin{array}{l}\text { Actual } \\
\text { weight }\end{array}$} & \multirow{2}{*}{$\begin{array}{c}\text { Ideal } \\
\text { weight }\end{array}$} & \multirow{2}{*}{$\begin{array}{l}\text { Serum } \\
\text { protein }\end{array}$} & \multirow{2}{*}{$\begin{array}{l}\text { Hemo- } \\
\text { globin }\end{array}$} & \multicolumn{3}{|c|}{ Actual volume } & \multicolumn{3}{|c|}{$\begin{array}{l}\text { Volume per kgm. ideal } \\
\text { weight }\end{array}$} \\
\hline & & & & & & $\begin{array}{l}\text { Whole } \\
\text { blood }\end{array}$ & Plasma & Cells & $\begin{array}{l}\text { Whole } \\
\text { blood }\end{array}$ & Plasma & Cells \\
\hline & & kgm. & kgm. & $\begin{array}{l}\text { grams } \\
\text { per } \\
100 \mathrm{cc.}\end{array}$ & per cent & liters & liters & liters & $c c$ & $c c$. & $c c$. \\
\hline 1 & 42 & 74 & 58.5 & 2.56 & 99 & 3.21 & 1.60 & 1.65 & 54.9 & 27.4 & 28.2 \\
\hline 2 & 23 & 116.4 & 71.9 & 2.20 & 62 & 3.99 & 2.63 & 1.35 & 55.5 & 36.4 & 18.9 \\
\hline 3 & 27 & 77 & 64.5 & 4.54 & 69 & 3.23 & 2.07 & 1.16 & 50.1 & 32.1 & 18.0 \\
\hline 4 & 47 & 68 & 62.5 & 4.71 & 85 & 3.71 & 2.22 & 1.48 & 59.2 & 38.5 & 23.7 \\
\hline 5 & 50 & 70 & 67.5 & 4.81 & 58 & 3.49 & 2.51 & 0.98 & 51.8 & 37.2 & 14.5 \\
\hline
\end{tabular}

per $100 \mathrm{cc}$. and the albumin-globulin ratio was inverted, 41 to 59 . The blood pressure was $140 / 85 \mathrm{~mm}$. $\mathrm{Hg}$. The urine showed enormous quantities of albumin, occasional casts, but no red cells.

The single blood volume determination on this patient showed a very low blood volume, $51.8 \mathrm{cc}$. per kilogram ideal weight; a very low cell volume, $14.5 \mathrm{cc}$. per kilogram ideal weight; and a normal plasma volume of $37.2 \mathrm{cc}$. per kilogram ideal weight.

\section{DISCUSSION}

The figures in these five cases of renal edema show that the total blood volume was markedly diminished at the time of greatest edema. In the first case in which there was no concomitant anemia the reduction was entirely in respect of plasma. In the remaining cases com- 
plicated by varying grades of anemia the plasma volume was less definitely reduced, being either just below the normal limit or near the lower limit of normal. In these anemic cases the cell volume was also reduced, being most reduced in the cases with the greatest anemia. In the four cases on which more than a single determination was made the blood volume increased markedly, almost entirely in respect of the plasma as the edema disappeared. In the anemic cases it seemed as though the plasma volume attempted to compensate for the diminished cell volume in order to bring the total blood volume to a normal level: in these cases therefore the plasma volume often rose to a figure much greater than that of the normal plasma volume.

It is clear from this that our results tend to be in agreement with the results of Darrow and of Plesch and generally opposed to those of Brown and Rowntree.

The figures we obtained indicate that the variations in the plasma volume are connected not so much with the amount of edema present in the individual patients as with the presence or absence of diuresis. Thus in cases 2, 3 and 4 the plasma volume had risen to normal or above normal long before the edema had disappeared. It would seem that when edema is collecting the plasma volume falls, and that while the edema is disappearing the plasma volume rises again. Hence it is possible that the edematous cases in Brown's and Rowntree's group had already begun to lose their edema, so that the initial stage of low plasma volume was missed.

Brown and Rowntree noted that cases of nephrosis with anemia tended to have blood volumes that were slightly above normal in respect of whole blood and of plasma. This is interesting in connection with our observation that in anemic edematous patients the plasma volume is not lowered to the same extent as in edematous patients without anemia, and that when diuresis has set in the plasma volume may rise above normal as if to compensate for the lowered cell volume and to bring the total blood volume up to the normal level.

Another factor that may explain some of the differences between our results and those of Brown and Rowntree is the difference in the two methods used. Brown and Rowntree used the dye method, whereas we used the carbon monoxide method. Personally we are of the opinion that there is considerable evidence that an appreciable part 
of the dye diffuses into the lymph spaces and thus includes a portion of the lymph volume in the determined "blood volume." We have given our reasons for this view in two other papers now in press. If that view is accepted it may be quite possible that in certain cases of renal edema the tendency for the dye to diffuse is greater than it is in normal individuals. In that event one would expect the dye method to fail to show a diminution in the blood volume of patients suffering from renal edema. It could also explain why during diuresis the dye method sometimes yields a diminution rather than an increase in plasma volume.

\section{SUMMARY}

A study has been made of the blood volume in five cases of renal edema by means of the carbon monoxide method.

The results obtained indicate that:

1. The blood volume is abnormally low when edema is at its height, that it increases as the edema disappears and may fall again if the edema subsequently reappears.

2. In a case uncomplicated by anemia the cell volume is normal and the changes are confined to the plasma volume.

3. When anemia is present there is a diminution in cell volume which is more marked the higher the degree of anemia. In anemic cases the plasma volume is less definitely reduced; and when diuresis sets in the plasma volume may rise above the normal as though to compensate for the diminished cell volume and to bring the total blood volume up to normal.

\section{BIBLIOGRAPHY}

1. Plesch, J., Ztschr. f. Klin. Med., 1922, xciii, 241. Untersuchungen über die Physiologie und Pathologie der Blutmenge.

2. Plesch, J., Ztschr. f. exp. Path. u. Therap., 1909, vi, 380. Hämodynamische Studien.

3. Linder G. C., Lundsgaard, C., Van Slyke, D. D., and Stillman, E., J. Exp. Med., 1924, xxxix, 921. Changes in the Volume of Plasma and Absolute Amount of Plasma Proteins in Nephritis.

4. Darrow, D. C., Proc. Soc. Exp. Biol. and Med., 1926, xxiii, 740. The Blood Volume in Cases of Nephritis with Edema and Low Serum Protein Concentration. 
5. Rusznyák S., and Erdös J., Biochem. Ztschr., 1929, ccvi, 482. Die Bestimmung der Eiweissfraktionen des Blutes mit der gravimetrischen und nephelometrischen Methode.

6. Brown G. E., and Rowntree L. G., Arch. Int. Med., 1925, xxxv, 129. The Volume and Composition of the Blood and the Changes Incident to Diuresis in Cases of Edema.

7. Brown G. E., and Rowntree L. G., Arch. Int Med., 1928, xli, 44. Blood Volume in Edema of Glomerular Nephritis and Nephrosis.

8. Chang H. C., and Harrop G. A., Jr., J. Clin. Invest., 1928, v, 393 . The Determination of Circulating Blood Volume with Carbon Monoxide.

9. Thompson W. O., Thompson P, K., and Dailey M. E., J. Clin. Invest., 1928, v, 573. The Effect of Posture upon The Composition and Volume of the Blood in Man.

10. Waterfield R. L., The Physiological Edema of the Legs in the Erect Posture. (In press.) J. Physiol., 1931.

11. Waterfield R. L., The Effects of Posture on the Circulating Blood Volume. (In press.) J. Physiol., 1931. 